\title{
Parameters for Public Space Architecture. Informal Commerce Dynamics, as an Opportunity to Stimulate Urban Scenarios. Case Study Cali-Colombia
}

\author{
Gustavo Arteaga ${ }^{1}$, Edier Segura ${ }^{1} \&$ Diego A. Escobar ${ }^{2}$ \\ ${ }^{1}$ Pontificia Universidad Javeriana Cali. Facultad de Humanidades y Ciencias Sociales. Departamento de Arte, \\ Arquitectura y Diseño. Calle 18 \# 118 - 250, Cali, 760031, Colombia \\ ${ }^{2}$ Universidad Nacional de Colombia, Sede Manizales. Facultad de Ingeniería y Arquitectura, Departamento de \\ Ingeniería Civil, Carrera 27 \# 64-60, Manizales, 170004, Colombia \\ Correspondence: Diego A. Escobar, Universidad Nacional de Colombia, Sede Manizales. Facultad de Ingeniería \\ y Arquitectura, Departamento de Ingeniería Civil, Carrera 27 \# 64-60, Manizales, 170004, Colombia. E-mail: \\ daescobarga@unal.edu.co
}

Received: July 5, 2018

Accepted: July 12, 2018

Online Published: July 15, 2018

doi:10.5539/mas.v12n8p27

URL: https://doi.org/10.5539/mas.v12n8p27

The research is financed by Pontificia Universidad Javeriana Cali.

\begin{abstract}
In the last decades, the occupation of the pedestrian routes and in general of the public space in the city center of Cali Colombia, have been evidencing diverse phenomena, which to a great extent respond to the accelerated growth of the urban population, where the migrations that have occurred in the interior of the country (fruit of the social conflicts of the last decades), have particularly marked the realities. In Cali, on 10th and 15th streets, near the Government Building, the Palace of Justice and the Municipal Administrative Center - CAM, the public space in general terms has been stressed in a particular way, which has generated conflicts in the surfaces designed for the pedestrians, since they are occupied by vendors in the midst of the informality routines, forcing the pedestrian to use the automobile tracks being a notorious and interesting phenomenon, when observing the factors that produce it and using them as parameters in the design of architectural spaces that contribute to improvement.
\end{abstract}

Keywords: public space, street vendor, informal commerce, pedestrians

\section{Introduction}

The city of Santiago de Cali, founded in 1536 , is located close to the south-western Colombian coast on the Pacific Ocean (Figure 1), it is undoubtedly the most important urban center of Colombia in that region, ranking by number of inhabitants (close to 2.5 million), as the third city with the largest population after Bogotá and Medellin (Torres \& Caicedo, 2015), demonstrating particular processes in recent decades, where the urbanization of the territory is one of the most important and constants phenomena. Within the main characteristics of the city, there is the warm, humid climate and the flat topography that accompanies the Cauca River Valley from north to south. From east to west there are changes in the topographic profile, since the presence of the western mountain range (within the Andes mountainous chain), makes the "Farallones de Cali" a particular element of the city landscape, where another important group of rivers are born, covering the urban and rural perimeter of the municipality of Cali, transferring differentiated landscape qualities.

The proximity to the port of Buenaventura ( 2 hours, $117 \mathrm{~km}$ ) over the Pacific has been a special factor in the city growth, which has generated a special bond between Cali and the port since the very colony in the XVI century (Pérez V., 2007), because of the difficult climatic conditions on the coast, Cali became a "dry port" (Zambrano \& Olivier, 1993) giving a commercial character to the city activities (Vásquez, 1990), but also, conditioning the national and world economic and productive cycles, most of the social dynamics since centuries ago, generating complex phenomena within the consolidation process of the city. The routines described within the urban development scenario, have encouraged growth in an accelerated manner in some periods, for example in 1918 along with Bogotá and Medellin (what was called the "golden triangle of Colombia") accompanied the coffee 
bonanza (Zambrano \& Olivier, 1993), which resulted in a major boost to urban development and where without doubt the construction of the railway opened in 1915 (Nieto, 2011) was another factor that markedly transformed the territory, since the need of perimeters for the new population became a constant, marking the forms of the city up to the present time (Jordan \& Simioni, 1998). The information previously given describes and also shows that many people settled in territories and nearby cities, were attracted by the conditions of Cali and sought in it better living conditions, promoting other phenomena such as migrations of "large magnitudes" (Banguero, 1980), which is still recognizable today; which at the same time produces a continuous mixture of cultures, which stresses in many ways the urban development of the city, by considerably expanding the spectrum of needs, since the heterogeneous characteristics of the groups that arrive multiply the variables and increase the sense of the basics in the visions of the state in its different scales of administration.

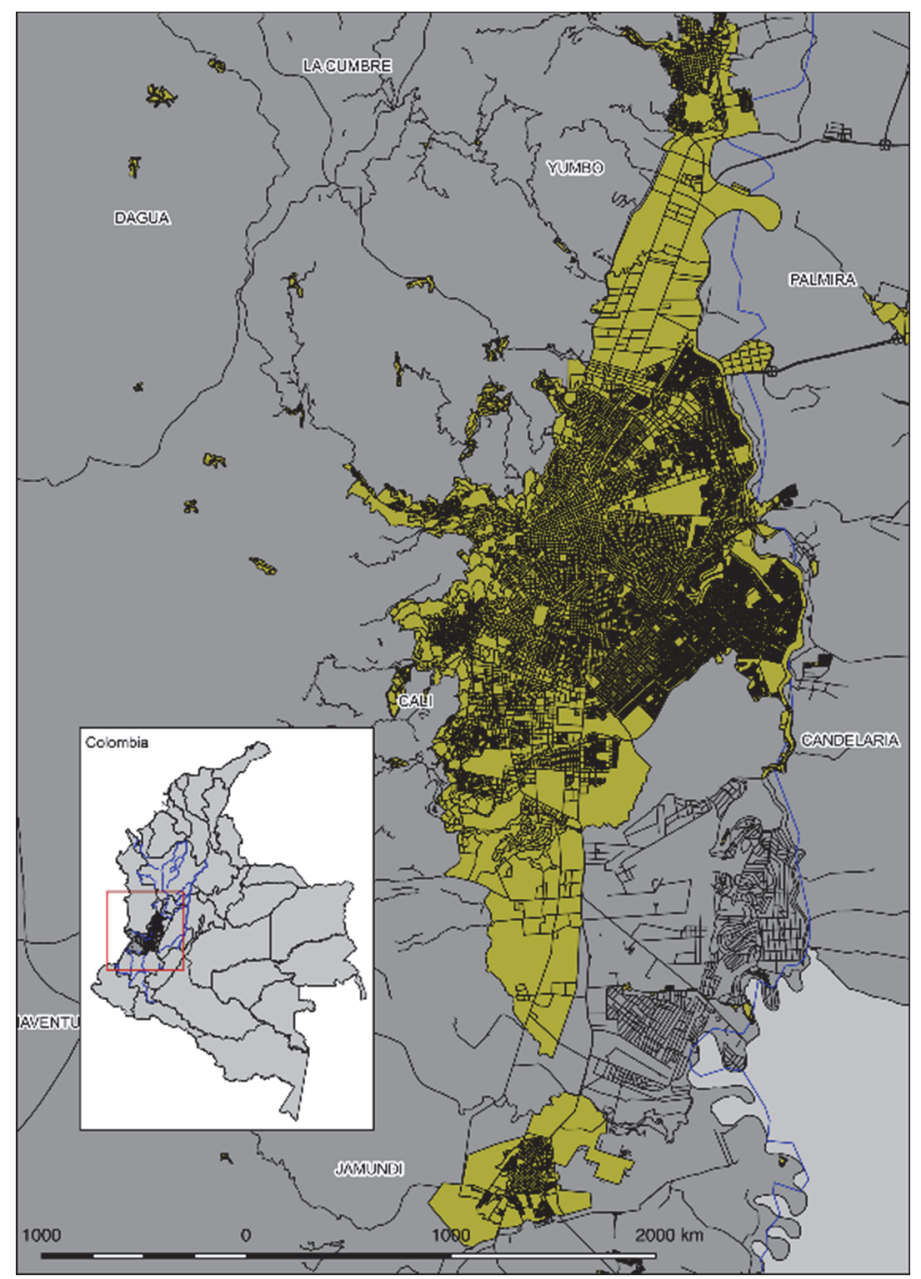

Figure 1. Location and urban layout of the municipality of Cali within the country and the region context. Source: Own elaboration using Qgis

The phenomenon of multiple cultures reaching a territory in the induced migratory dynamics, ended up being decisive during the XX century (Urrea, 2011) and becomes transversal in the consolidation processes that we can study today, configuring a particular challenge, since being phenomena that is estrange to the traditional logics of urban development (Lombard, 2012) given in other areas of the country, escapes the standard planning lines and is aggravated by the centralist model of Colombia, becoming conditions that impact the dynamics of public management at a departmental and municipal scale (Cabeza, 1998), causing that the structured policies designed to respond to conflicts that manifest and take greater magnitude over time, have little effect when defining objectives or implementing investment programs, resulting in short-term decisions that lose strength quickly; leaving only for the purposes of the economic cycles the scenarios, being the agents that accelerate, decant and complicate the phenomena described in multiple ways previously. Result of these, the labor dynamics (without clear intervention of the state), is characterized by marked peaks of activity, and being the main motivator of 
migration, causes that what we can call bonanzas, urbanization phenomena (formal and informal) ) accelerate with all the associated consequences and in times of low performance, the purchasing power falls significantly, affecting the social routines, dramatically modifying the conditions of the recently settled population as occurred in 1990 (Pérez et al., 2014 ).

These scenarios (apparently antagonistic), come along with direct effects on the way in which the city develops (understood as the process of consolidation of urban surfaces and nearby perimeters), emphasizing on the need to study the characteristics of the labor market to completely understand the ways of this development and this is where the informal characteristic of the labor market is framed as a little explored place and referenced within the context of the country.

The high informality of the last decades in Cali city (Bejarano, 2016), has caused the particular phenomena in the development to be defined in the ways of use of the surfaces (Group of Investigation Urban Processes in Habitat, 2009), firstly where the use of public space (especially the center of the city) is the opportunity to understand in a physical way what is stated up here in a theoretical way and placing as a basis that what today converges in a complex and confused way in a "dispute" (Arroyo \& Burbano, 2014), it is a resulting phenomenon that must be seen in a different way starting from the characteristics that are displayed today (see Figure 2).

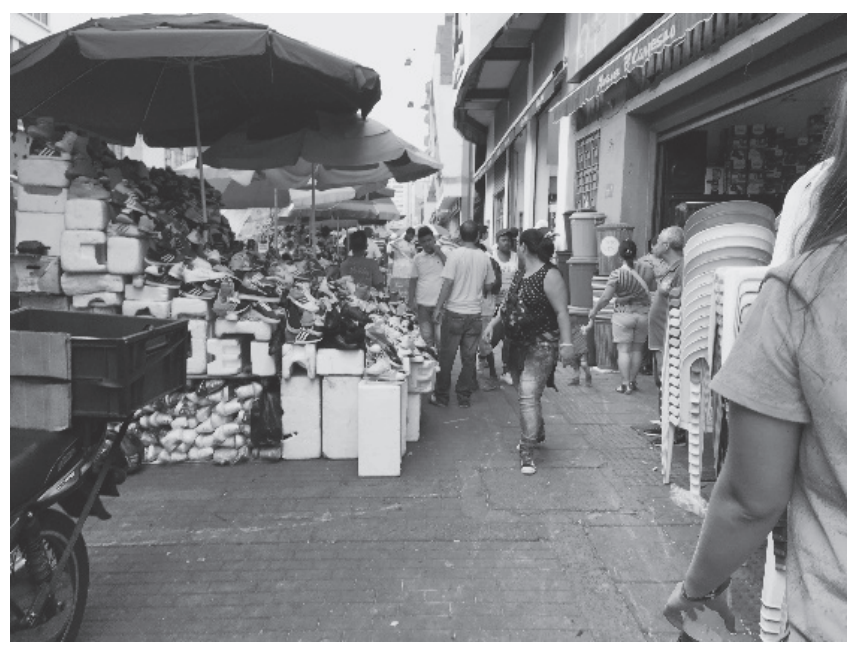

Figure 2. Invasion of sidewalks by informal vendors in downtown Cali. Photo by Edier Andres Segura 2016

The location of informal vendors in the public areas of the center, (designed and built for other purposes by the municipal administration), are transformed into "opportunity scenarios ", where activities can be developed to produce sufficient monetary income and subsist (Franco \& Molina, 2015), for which there are specific characteristics that have to do with the location and the surroundings that facilitate commercial operations (Rocha, 2006), being observable parameters from the logic of localization and specialization of the activities that take place temporarily, what is a matter of interest for the research, to propose an experimental routine of geolocation of information, which is proposed as an analysis methodology. Therefore, the collection and structuring of the information is established as a starting point, starting with the characterization of the phenomena in aspects to relate and demarcate the patterns associated with the routines, which induce the use of the surfaces and generate conflicts to establish the conditions that appear in the phenomena.

\section{Overview of the Study Area}

The sector of the center delimited in the investigation (see Figure 3) is characterized by an informal trade under an already treated framework (Figure 4), which is already stationary, which is positioned on the pedestrian routes (platforms), generating forms of organization that respond to various logics such as: the type of merchandise that is commercialized, the proximity to main roads, the tolerance of the authorities and owners or that the surfaces are suitable to be used (among the most notorious at first glance), however the observation also evidences more complex organizational processes on which we want to investigate in detail and with other analysis tools. In a first approximation, the highest concentrations of street vendors occur between identifiable or significant nodes in the center's imaginary, which generate tensions of use, such as the CAM with the Palace of Justice (see Figure 5), transferring the phenomenon of tension to specific road axes such as: 12th and 14th streets with carreras 6th and 9th; where the informality already described, alter the mobility, (specifically the pedestrian in the case of 
occupation of sidewalks), since the surfaces end up being occupied to develop the commercial activities.

By being arranged on measurable and identifiable road corridors, it is possible to observe informal trade and evidence specific conditions and characteristics, which can be structured in tables to see the relationships they cause and the public surfaces patterns of use by sellers that can be given. The type of commercialized merchandise and the number of sellers present in the road axes of interest are the first variables to structure information. When structuring the information of the variables presented in tables (see Table 1), it is seen that the fashion and accessories vendors are those that make the most use of pedestrian surfaces, which is of particular interest. By transferring this information already structured to other tools, it is possible to visualize localized relationships in the territory and see intensities that suggest changes in the special conditions, which represent other characteristics that can be unfolded to better understand the conditions that affect the use of pedestrian surfaces in the sector of interest.

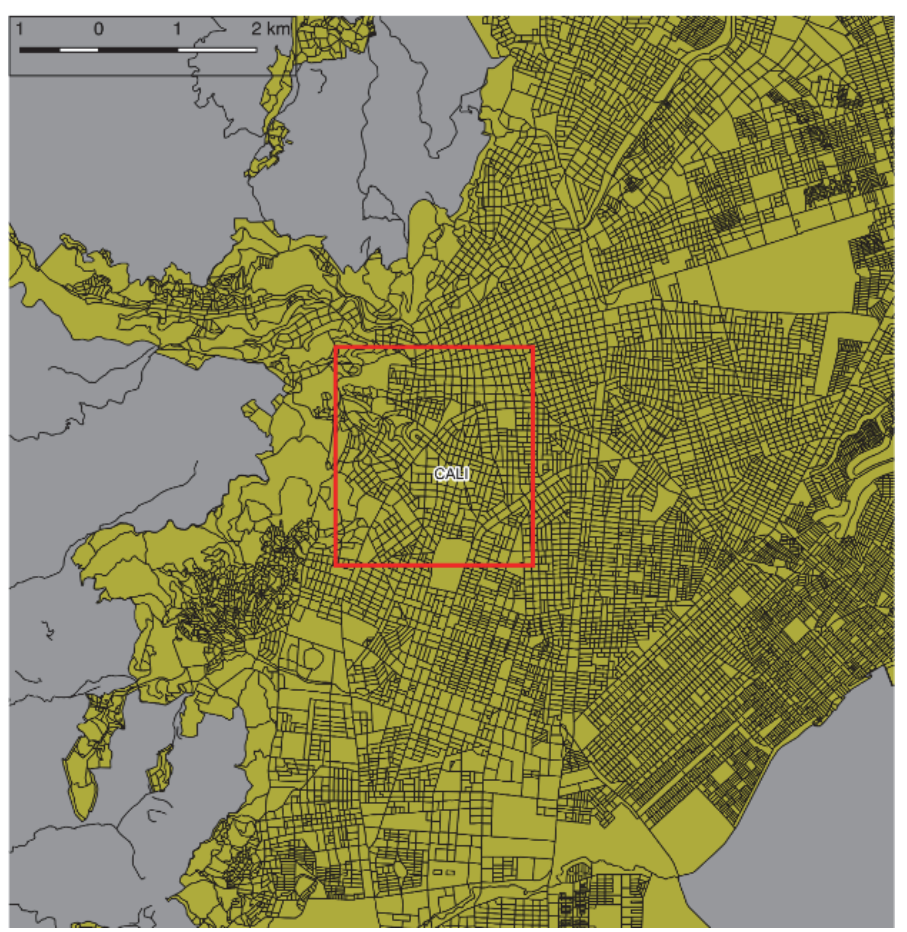

Figure 3. Perimeter of the traditional center of Cali. Source: self made

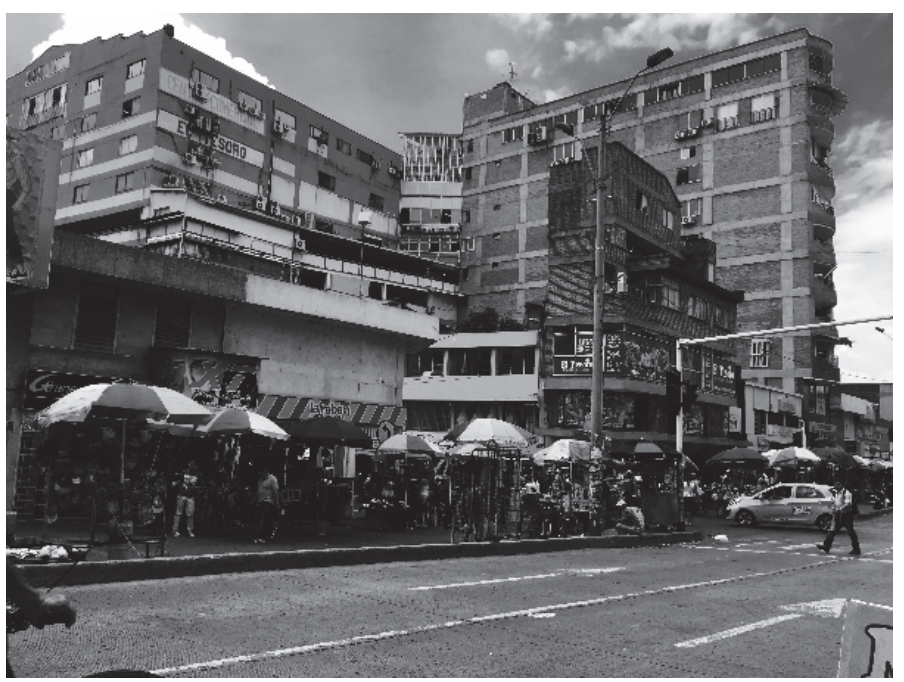

Figure 4. Invasion of sidewalks by informal vendors in downtown Cali. Photo by Edier Andres Segura 2016

Table 1. Quantity of informal vendors located on the sidewalks 


\begin{tabular}{cc}
\hline Type of traded items & Number of informal vendors located on sidewalk \\
\hline Food & 51 \\
Fruits and vegetables & 37 \\
Fashion & 186 \\
Accessories & 150 \\
Herbs & 6 \\
Gaming & 23 \\
\hline
\end{tabular}

\section{Materials and Method}

According to the considerations previously made, the relationships between the described variables can be defined in as follows: number of sellers, type of merchandise for sale (see Table 1) and location in the identified road corridors, using the ways of standard representation of geography as it is a map, but the amount of data that can be associated to these variables from attributes structured and collected in the field makes it possible to incorporate more variables into the analysis, allowing the study scenario to be more complex and visualize from other relationships the particular ways that induce the uses of public surfaces in the center of Cali city from the specific activity of informal sales.

Figure 5 as the first exercise to locate the characteristics of stationary informal trade in the center of Cali city shows dynamics and some logics that are the result of urban physical factors, which have to do, first of all, with the number of people and the type of uses of the buildings that frame the context of the activity, which according to the urban scale of the affected services transfers more or less intensity of use, such as the CAM node or the Palace of Justice node, which differentially affect nearby perimeters because they summon more (for the type of service provided in the city).

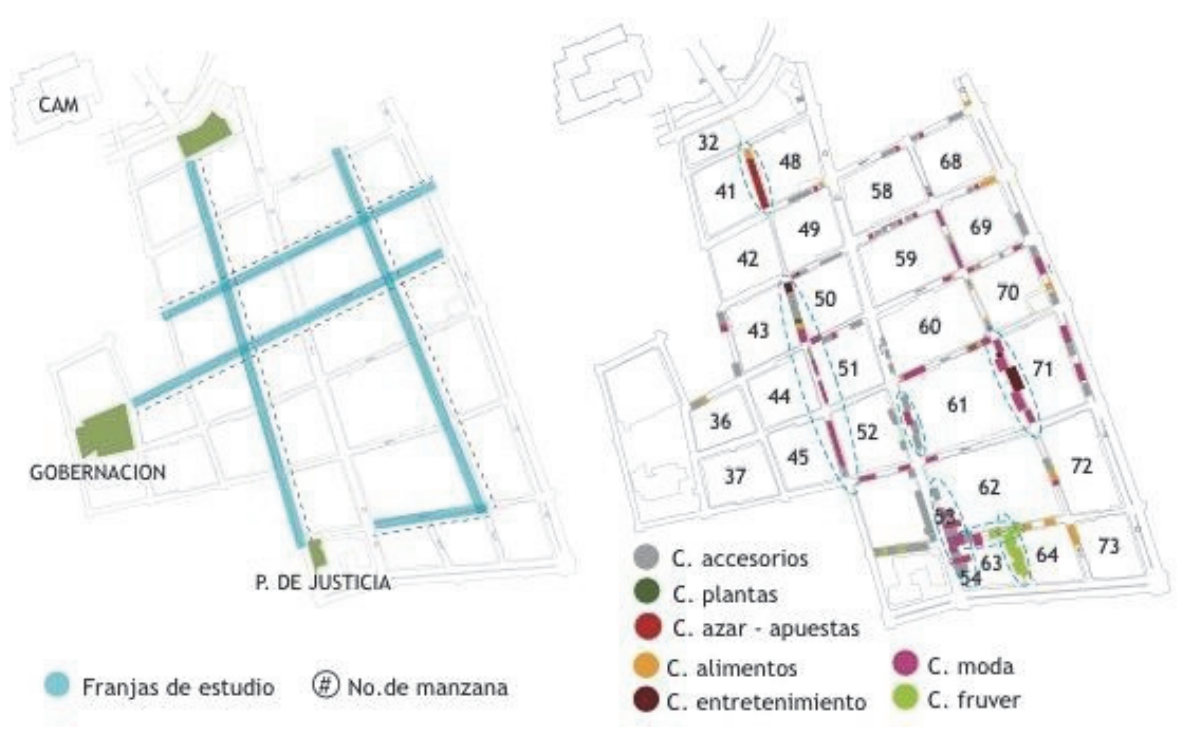

Figure 5. Location according to basic characteristics associated with the type of products for sale. Source: selfmade

This condition (with respect to the differential way in which some nodes attract activity), allows us to understand that the "density of vendors" depends on the context where these nodes are located and that these have logics that are shaped by the circumstances associated with the use of the surfaces, therefore the "intensity of use" is a result that is transferred directly to the surface where the crossing is located and the magnitude with which it occurs is the same intensity already described. In this sense, the density and intensity (understood from the urban context), allows configuring the activity scenario, to be able to deform it and adjust it to the specific degree of use (intensity) and diminish the negative effects, such as the displacement of vulnerable road actors (such as pedestrians) and expose it by forcing it to compete for spaces at times of maximum demand or intensity of use.

The activity scenario of interest, under the parameters defined previously, are framed as the space to use information analysis methodologies, which are based on the data collection (which describe the observed characteristics), where geolocation must be the parameter of articulation, which as a node, will link the data, so 
that as they unfold, incorporate or expand, they can be contrasted in different relationship scenarios and produce the characteristic facets (that explain from delimited methodological frameworks), the conditions and characteristics of the phenomenon, its degree of relationship and the magnitude with which it varies according to the change in the variables.

Therefore, the systematization of the relevant data will link the data with its spatial attributes to form the data packages and scenarios where the contrasts can be visualized. In this sense, Figure 5 is the basis of analysis to make the discrimination of the characteristics, where the use of the visualization tools developed by Google and where the data presented in the generalities, will be the methodological structure to study the phenomenon of confrontation by the public space, understood as the public surfaces of free and public use of decree 1504 of 1998 (Mayor's Office of Bogotá, 2012), in the sector of interest. The classification of the sellers in Table 1, shows a specialization in the first measurement of the sales that are made according to the offered articles, being something of interest since it allows to see logics in the distribution that surpass the supposed randomness that is intended to be associated from visions of the exercise of informality.

The Method section describes in detail how the study was conducted, including conceptual and operational definitions of the variables used in the study, Different types of studies will rely on different methodologies; however, a complete description of the methods used enables the reader to evaluate the appropriateness of your methods and the reliability and the validity of your results, It also permits experienced investigators to replicate the study, If your manuscript is an update of an ongoing or earlier study and the method has been published in detail elsewhere, you may refer the reader to that source and simply give a brief synopsis of the method in this section.

\section{Results}

When visualizing with heat maps, it is possible to observe with greater precision the patterns around specific places and the intensities that have been referenced and Figure 6 is the first resulting cartographic element, where the routines of interest are manifested in the road axes according to the direction of the nodes referenced but the intensities that show different patterns display a greater level of detail contributed by the tool and when contrasting with Figure 5 denotes other types of phenomena associated with the same data.

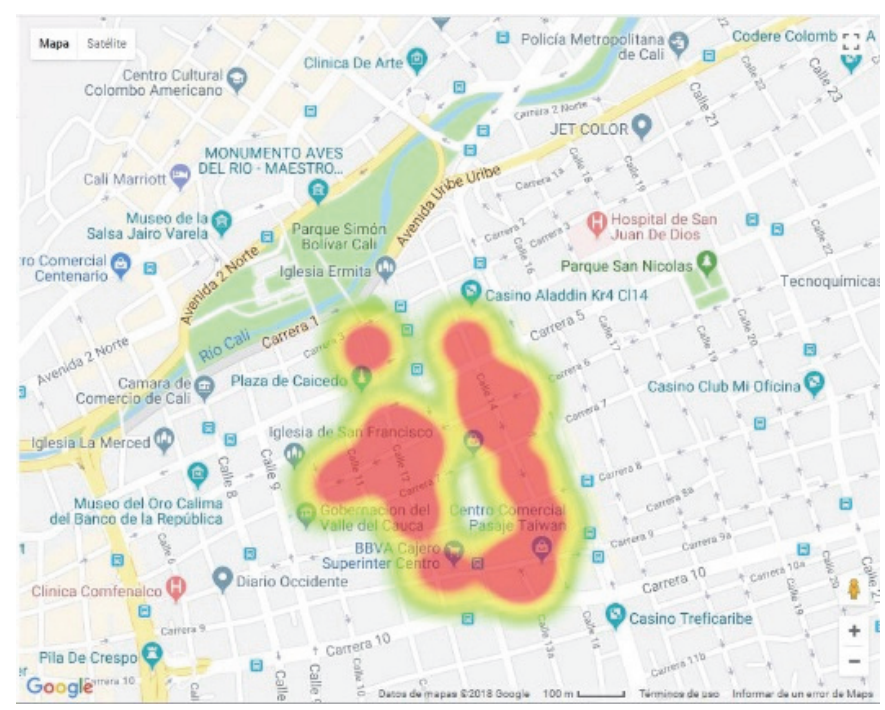

Figure 6. Road axes where informal street sales are characteristic in the Cali city center. Source: Own elaboration using Google tools

The use of the tool according to the structured and proposed methodology, allows to disaggregate and view the information, using as backup the sector map, with which it is possible to discriminate by type of sales, the variables defined as: intensity, density and magnitude of use of the surfaces according to the activity to delimit performance perimeters that adjust to the level of demand or the collateral uses that are presented. First of all, it highlights the specialization that occurs in sales according to what is marketed and the specific maps permit to visualizing it:

a. Figure 7 Affectation of pedestrian surfaces according to informal accessories sales.

b. Figure 8 Affectation of pedestrian surfaces according to informal food sales. 
c. Figure 9 Affectation of pedestrian surfaces according to informal sales of gambling.

d. Figure 10 Affectation of pedestrian surfaces according to informal fashion sales.

e. Figure 11 Affectation of pedestrian surfaces according to informal sales of plants (herbs).

In the fashion accessories sales according to Figure 7, the 14th street between the Carreras 5 th and 6th have the highest degree of intensity. The food sales in Figure 8 is placed on the road axis of the Carrera 6th between 10th and 11th streets. The sale of gambling in Figure 9, on 12th street between Carreras 3rd and 4th, the fashion sales in the streets 12 and 14 between the Carreras 7th and 8th Figure 10 and the plants and / or herbs sales according to Figure 11, 14th street between Carreras 5th and 7th.

In the developed research (by the methodology used and the addressed subject of interest), a detailed analysis of a sector of the center of Cali city is produced, where it is visualized (with the use of Google geolocation tools), the occupation of specific public spaces by the so-called informal vendors, where the pedestrian surfaces in particular, show a specific affectation, that today is understood as conflictive, by the competition for the use that is given by these urban surfaces.

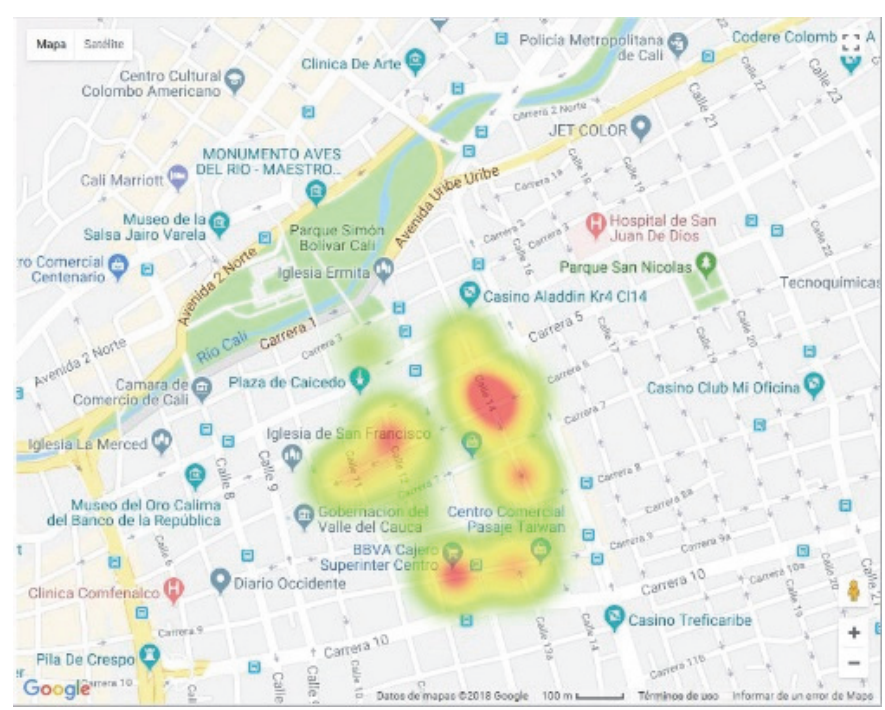

Figure 7. Affectation of pedestrian surfaces according to informal accessories sales. Source: Own elaboration with Google tools

The densities and their magnitudes, which show the heat maps, allow us to understand that the informal commerce generated in specific places of the center, produce phenomena that respond to the type of merchandise that is commercialized, and with this, the first patterns from which little is known in the specialized literature. In this sense the labor informality that produces street sales has not been studied in depth from urbanism or disciplines that address the urban aspects, so many details and considerations that show the previous relationships have not been registered, so the degree of uncertainty regarding the actions taken by the municipal administration (in defense of the use), have side effects in sectors of the population that have few guarantees because the population is registered as vulnerable in the needs scenarios, which it is a counter-sense in all public policies, since these populations are the ones that should have the most guarantees within the framework of the administration's priorities. 


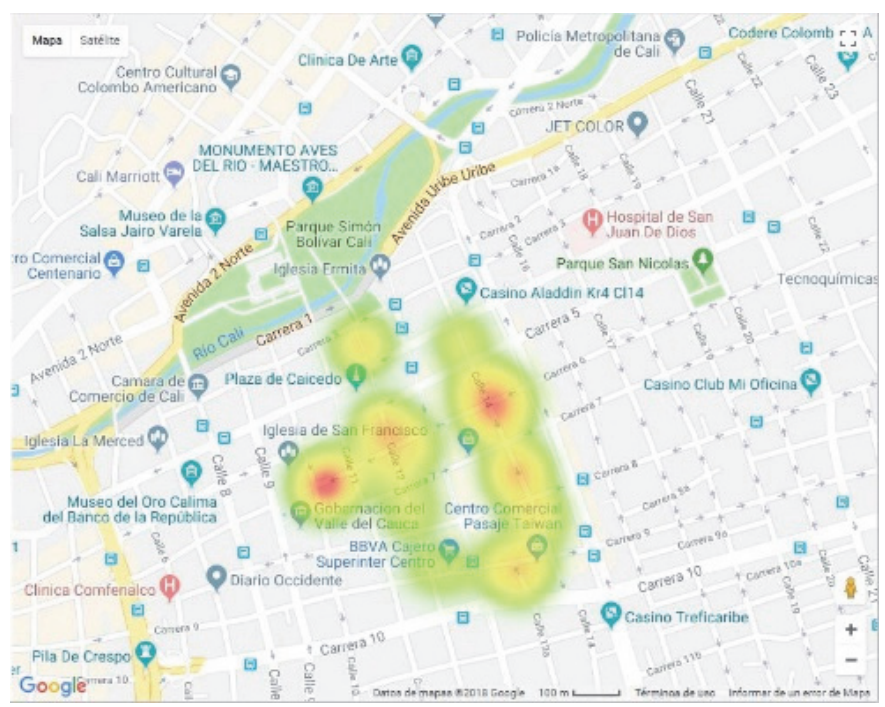

Figure 8. Affectation of pedestrian surfaces according to informal food sales. Source: Own elaboration with Google tools

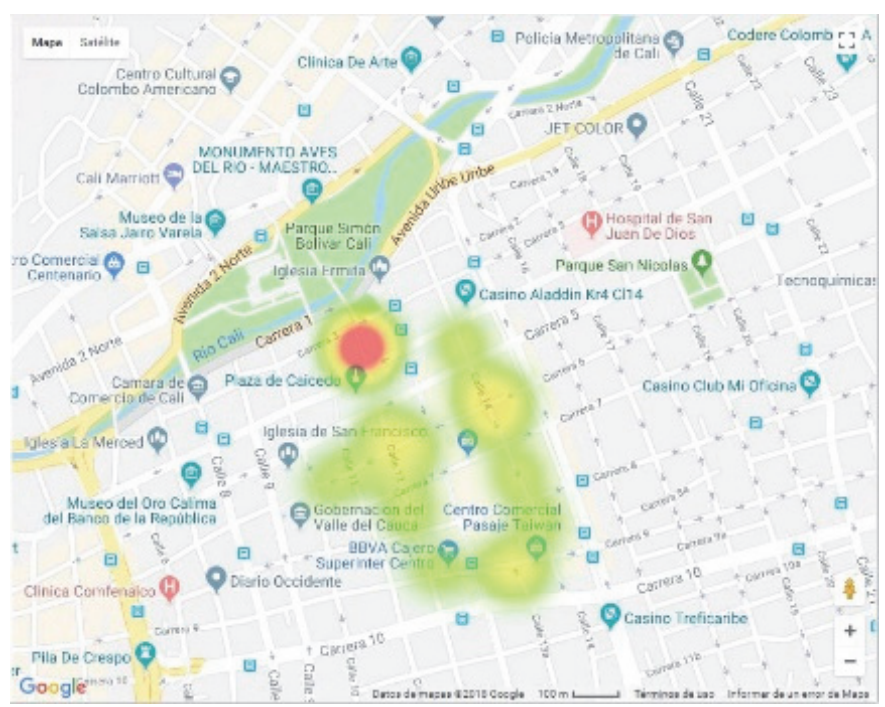

Figure 9. Affectation of pedestrian surfaces according to informal sales of gambling. Source: Own elaboration with Google tools

The consolidation of the information in tables and maps in this research, generated a first diagnosis with an experimental methodology of a phenomenon that occurs in a sector of the city center, but also produced a matrix of characteristics to consolidate, to propose adjustments in the methodologies of traditional analysis, which when addressing the subject from generalized and standardized planning frameworks, induce negative collateral phenomena, with which adding attributes in the matrix that incorporate a greater degree of complexity in conflictive scenarios of public space use, is a result of great importance because it proposes other approach forms and alternatives to obtain results with the possibility of direct use in the design of both policies and urban projects in these sectors. The research suggests that it is necessary to rethink urban renewal projects (Gausa, 1997), which allow the humanization of public space in all its dimensions responding to time and its context, generating models that define social, environmental and economic strategies that make it possible to improve conditions of conflict and in this point the spectrum of opportunities that new tools of information management give with respect to the way of thinking about the city, should be incorporated. 


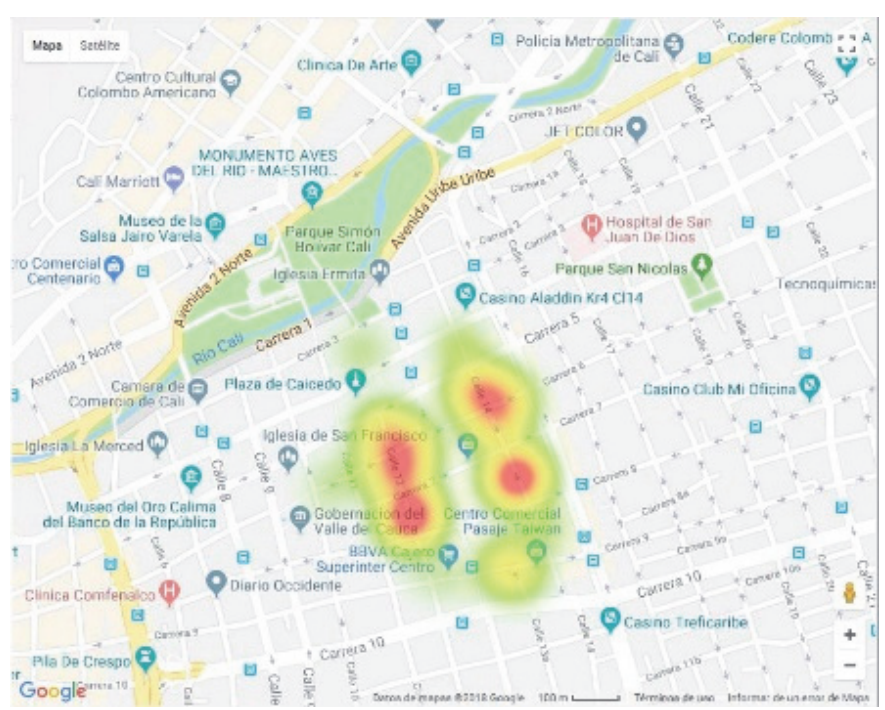

Figure 10. Affectation of pedestrian surfaces according to informal fashion sales. Source: Own elaboration with Google tools

\section{Discussion}

The elaborated maps allow to visualize that the urban surfaces used by the informal vendors in the city of Cali, present patterns that allow the characterization of the zones in a theoretical way and within the logic of proposing alternatives that give solution to conflicting routines associated to the use of the public space, it is possible that these patterns are guidelines to give specific answers, and from the adjustment of the same surfaces, (taking into account the specific factors of each scenario) to ensure the permanence of the actors in conditions of "use balance", which is defined as a concept to be designed in the instruments of territorial ordering and pertinent urban regulatory framework. It is interesting to see that the densities evidenced in the heat maps (Figure 7 to Figure 11), allow us to understand that there are distributions with specialization according to basic elements (as in the case of this study, the merchandise that is commercialized), with which the design of suitable places for the different practices (understanding from the point of view of architectural space), in a routine of providing space of labor opportunity is possible, adding variables of balance according to uses and immediate urban context, with which "the surfaces of opportunity "is a second concept that allows design to be incorporated as a planning tool.

This is a method that allows progress in the generic way in which the phenomena of informal vendors are understood today, where the common action forces relocations to solve the conflict, which produces collateral conflicts, such as when the vendors abandon the spaces delivered and return to the places from which they were originally displaced, which can be seen in cities such as Manizales, Pereira, Medellín, and Bogotá among others, evidencing waste and poor focus of the investments.

The specialization of product marketing routines, in the logic of informality, can be understood as an opportunity, in terms of allowing the facial association or cooperation, which produces a more agile management in decisionmaking and the rapprochement between actors. Which is undoubtedly a facet to be explored by the magnitude that has taken the phenomenon in different cities and proposes it as a way of participatory projects and empowerment of the administration of public surfaces with precise responsibilities among the actors that translates into continuity of the projects and the consolidation of trust with populations historically poorly treated by the state.

The strategies that the last public administrations of the city have implemented in response to this phenomenon have not been appropriate, and their measures are also based on relocation (in empty places in the commercial centers of the sector, or sent to Parque Comercial Rio Cauca, in the periphery of the city) where the minimum sales guarantees that would allowed them to have income, was not a factor associated with the project, which generated the returning of the premises and the vendors to return to their usual spaces, demonstrating punctually what was described in the first paragraphs. 


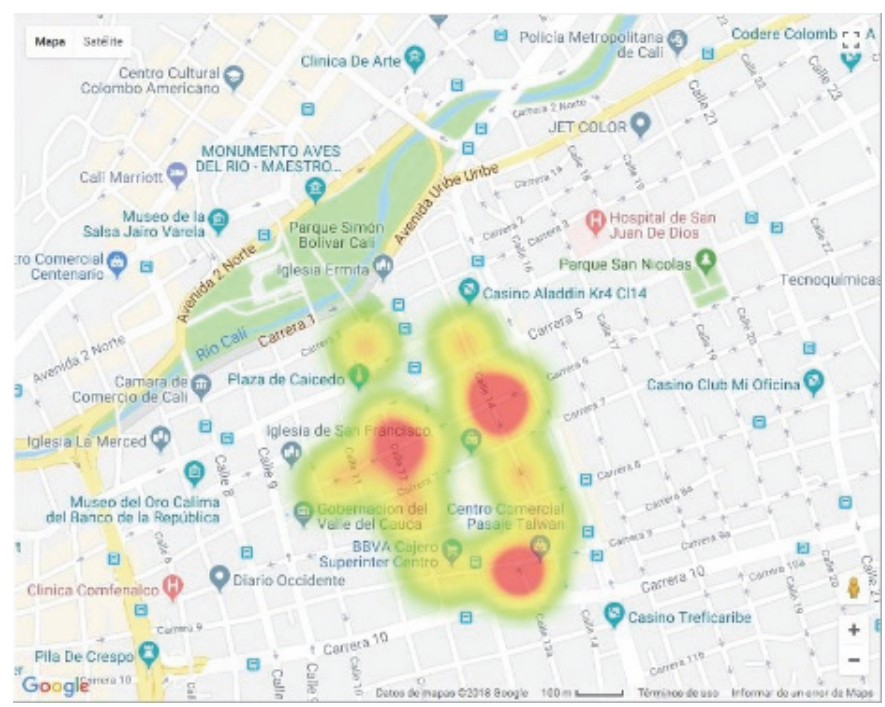

Figure 11. Affectation of pedestrian surfaces according to informal sales of plants (herbs). Source: Own elaboration with Google tools

\section{Conclusions}

A first general conclusion points out that at the time the Santiago de Cali center was planned, it was not thought to assume and respond to the phenomena caused by the current marked growth, which is why it has been facing dynamics that generate different alterations of the urban structure and especially in the oldest sectors; which translates into a contradiction, since sectors of the city with possible degrees of historical and patrimonial value are pressured with greater force (as in the case of Cali) facing phenomena typical of "modernity", such as automotive and use density.

By looking in detail at the phenomenon of stationary informal vendors in the Cali city center, one could quickly see the relationship between the presence of vendors and the proximity to significant and traditional urban nodes such as churches, plazas, parks or public buildings, and those nodes, having a relationship through road corridors generate tensions, it is possible to easily identify the different elements in relation that produce the phenomenon. In this sense, the road profiles are presented as a "space of opportunity" that, according to the precise adjustment that is made, allow the coexistence of different urban routines, without reaching conflicting conditions such as the one evidenced in the investigation with the invasion of pedestrian space.

The results of this research show the growth of informal employment in the city of Cali, which tends to subtract pedestrian surfaces, altering urban conditions of great importance. Because of this, it is proposed that many areas of the center should be reorganized according to the observed characteristics, and proposed as a process of "formalization" (according to the investigation), seeking to return the public space to the pedestrian in a practice that In recent years has been called "humanizing public space" (Ministry of Urban Development, 2009).

\section{References}

Arroyo, A., \& Burbano, A. (2014). La investigación sobre el espacio público en Colombia: su importancia para la gestión urbana. Territorios, (31), 185-205. Retrieved from http://revistas.urosario.edu.co/index.php/territorios/article/view/2902

Banguero, H. (1980). El proceso Migratorio en Colombia: Determinantes y Consecuencias, 23-36. Retrieved from http://bibliotecadigital.univalle.edu.co/bitstream/10893/5391/1/El\%20proceso $\% 20$ migratorio $\% 20 \mathrm{en} \% 20 \mathrm{Col}$ ombia\%20Determinantes $\% 20 \mathrm{y} \% 20$ consecuencias.pdf

Bejarano, M. S. (2016). Entorno geográfico. Entorno Geográfico, (12). Retrieved from http://entornogeografico.com/index.php/EntornoGeografico/article/view/129/128

Cabeza, A. M. (1998). Determinantes de los planes de ordenamiento territorial. Perspectiva Geográfica, 7-70. [Date accessed: 20/11/2015].

Franco, I., \& Molina, S. (2015). Obtenido de Caracterización sociodemográfica de los vendedores ambulantes de la zona céntrica de Santiago de Cali. Biblioteca Digital $U$. Icesi. Retrieved from https://repository.icesi.edu.co/biblioteca_digital/bitstream/10906/79391/1/TG01243.pdf 
Gausa, M. (1997). Repensando la movilidad. Retrieved May 2, 2017, from http://textosenlinea.blogspot.com.co/2008/05/manuel-guasa-repensando-la-movilidad.html

Grupo de Investigación Procesos Urbanos en Hábitat. (2009). Ciudad Informal Colombiana. (C. A. Tovar, Ed.) Editorial Universidad Nacional de Colombia, Bogotá. Retrieved from https://revistas.unal.edu.co/index.php/bitacora/article/view/18631

Jordan, R., \& Simioni, D. (1998). Ciudades intermedias de América Latina y el Caribe: Propuestas para la gestión urbana. Cepal, $450 . \quad$ Retrieved from http://repositorio.cepal.org/bitstream/handle/11362/31024/S9800066_es.pdf?sequence=1\&isAllowed=y

Lombard, M. (2012). Planeamiento Insurgente en Asentamientos: un estudio de caso en Cali, Colombia. Cuadernos de Vivienda y Urbanismo, 5(10), 246-260.

Mayor's Office of Bogotá - Alcaldía Mayor de Bogotá (2012). Decreto Nacional 1504 de 1998. Retrieved from http://www.alcaldiabogota.gov.co/sisjur/normas/Norma1.jsp?i=1259

Ministry of Urban Development - Ministerio de Desarrollo Urbano. (2009). La humanización del espacio público. (Introducción). (G. de la Ciudad., Ed.). Buenos Aires.

Nieto, C. (2011). El ferrocarril en Colombia, la búsqueda de un país. Apuntes, 24, 62-75. Retrieved from http://revistas.javeriana.edu.co/sitio/apuntes/sccs/plantilla_detalle.php?id_articulo=272.

Pérez V., G. J. (2007). Historia, geografía y puerto como determinantes de la situación social de Buenaventura. Centro de Estudios Económicos Regionales. Retrieved from http://www.banrep.gov.co/docum/Lectura_finanzas/pdf/DTSER-91.pdf

Pérez, G., Aguilera, M., Otero, A., Sánchez, A., Acosta, K., \& Galvis, L. (2014). Economía de las grandes ciudades en Colombia: seis estudios de caso. In Economía de las grandes ciudades en Colombia: seis estudios de caso (p. 161). Retrieved from https://books.google.es/books?hl=es\&lr=lang_es\&id=yHrxBwAAQBAJ\&oi=fnd\&pg=PT3\&dq=Caucho+y + llanta $+\mathrm{y}+$ reciclaje $+\mathrm{y}+$ colombia\&ots=P-R5cSw8AP\&sig=D4ga4dTI0jUTDNZ-eVJnxPOYq_I

Rocha, R., Sánchez, F., \& García, L. (2009). Ventas callejeras y espacio público: Efectos sobre el comercio de Bogotá. Desarrollo y Sociedad (63), 245-268. Retrieved from https://revistas.uniandes.edu.co/doi/pdf/10.13043/dys.63.6

Torres, P., \& Caicedo, C. (2015). Las ciudades intermedias con mayor potencial en Colombia: Un sistema de identificación. Banco Interamericano de Desarrollo. Departamento de Países Del Grupo Andino, 40. Retrieved from https://publications.iadb.org/bitstream/handle/11319/6890/Las_ciudades_intermedias_con_mayor_potencial _Colombia.pdf? sequence $=1$

Urrea, F. (2011). Transformaciones sociodemográficas y grupos socio-raciales en Cali a lo largo del siglo XX y comienzos del siglo XXI \&quot; Retrieved from http:/www.urosario.edu.co/urosario_files/b4/b4eff1cc4195-4089-b3bc-dd0290d67fb8.pdf

Vásquez, E. (1990). Historia del desarrollo económico y urbano en Cali. Boletín Socieconómico $N^{\circ} .20,28$.

Zambrano, F., \& Olivier, B. (1993). El proceso de poblamiento en Colombia. (Tercer Mundo, Ed.). Bogotá. Retrieved from http://datateca.unad.edu.co/contenidos/90160/AVA_2.X/Entorno_de_Conocimiento/Ciudad_Territorio_Proc eso-Zambrano_F-1993.pdf

\section{Copyrights}

Copyright for this article is retained by the author(s), with first publication rights granted to the journal.

This is an open-access article distributed under the terms and conditions of the Creative Commons Attribution license (http://creativecommons.org/licenses/by/4.0/). 